\title{
An epidemiological assessment of coagulase-negative staphylococci from an intensive care unit
}

\author{
SIEGLINDE WALCHER-SALESSE, C. MONZON-MORENO, SYLVIE AUBERT and NÉVINE \\ EL SOLH*
}

Centre National de Refference pour les Staphylocoques, Laboratoire des Staphylocoques et des Streptocoques, Institut Pasteur, 75724 Paris Cedex 15, France

\begin{abstract}
Summary. Detection of an unusual combination of four resistance markers among coagulasenegative staphylococci (CNS) isolated in the same intensive care unit led to the undertaking of an epidemiological assessment. Seventeen CNS isolates from the same unit and 38 epidemiologically unrelated Staphylococcus epidermidis isolates were typed by eight methods, including analysis of immunoblot patterns and hybridisation patterns (HP) obtained with three probes. The probes comprised plasmids carrying the genes encoding 16S rRNA (pBA2), aacA-aphD (pSF815A), and aacA-aphD with part of IS256 (pIP1307). Immunoblot patterns and HP with pIP1307 indicated that 14 of the 17 CNS isolates from the same unit resulted from the spread of an epidemic strain.
\end{abstract}

\section{Introduction}

Coagulase-negative staphylococci (CNS) are found commonly on the body surfaces of man and animals. ${ }^{1}$ Staphylococcus epidermidis is the most prevalent species in normal skin flora, ${ }^{1}$ and also the most prevalent causative agent of opportunist infections associated with implanted medical devices. ${ }^{2-11}$ The ubiquitous nature of CNS has posed problems in deciding the significance of an individual isolate as a causative agent of infection. Assessment is based on the clinical condition of the patient and the presence of closely related isolates in subsequent specimens taken from the patient. Outbreaks of nosocomial infections caused by epidemic strains have been reported, but conclusive evidence has been established rarely ${ }^{12-17}$ Indeed, it is difficult to conclude that any two isolates are closely related because of phenotypic variations often observed among $\mathrm{CNS}^{16,18-20}$ and the limitations of the traditional methods used to type CNS. ${ }^{21-24}$ These methods include biotyping, ${ }^{15,}$ 25-29 drug resistance phenotyping, ${ }^{15}, 25,27,30,31$ phagetyping ${ }^{27,} 29,32-38$ and serotyping. ${ }^{39}$ Various molecular

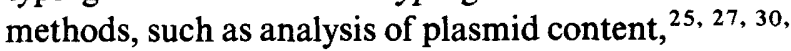
${ }_{31,40-44}$ cellular DNA restriction patterns, ${ }^{45,46}$ restriction polymorphism of the rRNA gene region, ${ }^{47-51}$ electrophoretic profiles of the cellular proteins, ${ }^{29}$, $31,50,52-56$ immunoblotting profiles ${ }^{46,52,56}$ and analysis of cellular fatty acids, ${ }^{57}$ have been utilised in an attempt to overcome these problems. This paper contains an epidemiological assessment of CNS

Received 29 April 1991 ; accepted 8 July 1991.

*Correspondence should be sent to Dr N. El Solh. isolated in the intensive care unit of a Parisian hospital. Of the $198 \mathrm{CNS}$ isolated in this unit over a 5month period in $1989,37(19 \%)$ had numerous common antibiotic resistance markers, including resistance to pefloxacin, rifampicin, fusidic acid and fosfomycin. This combination was unusual in comparison with the normal resistance phenotypes encountered among CNS isolated in other French hospitals and sent to our reference centre. Since these four antibiotics were in common therapeutic use in the intensive care unit, the prevalence of such CNS could result from dissemination of an epidemic strain of CNS or from selection of resistance in unrelated isolates. Of the $37 \mathrm{CNS}$ isolates from the same unit, 17 were typed by eight methods, including hybridisation with three probes previously described for typing $S$. aureus ${ }^{58}$ and immunoblotting with a rabbit antiserum raised against a $S$. epidermidis strain. In addition to the 17 isolates from the same unit, 38 S. epidermidis isolates from different geographical areas were also included in this study to evaluate the discriminatory power of the new typing methods.

\section{Materials and methods}

\section{Bacterial strains and plasmids}

The CNS studied consisted of $38 \mathrm{~S}$. epidermidis isolates originating from different geographical areas (10 isolates from 10 states in the USA and 28 isolates from 11 French cities) and 17 isolates obtained between 6 Jan. 1989 and 18 May 1989 in an intensive care unit in Paris. The 17 latter isolates were resistant to pefloxacin, rifampicin, fusidic acid and fosfomycin, 
and were isolated from blood cultures and intravascular catheters of 17 patients with clinical evidence of infection. For 12 of these patients, at least two CNS resistant to the four antibiotics were isolated from two independent blood samples.

Escherichia coli strains used were SF8, SF815A and BM3887, harbouring plasmids pBA2, pSF815A and pIP1307 respectively. ${ }^{59-61}$ Plasmid pBA2 consists of a 2-3-kb Bacillus subtilis DNA fragment encoding $16 \mathrm{~S}$ rRNA inserted in the HindIII site of pBR322. Plasmid pSF815A consists of pUC8 with a $1.5-\mathrm{kb}$ AluI insert carrying the Enterococcus faecalis aacA-aphD gene specifying the bifunctional enzyme AAC6'-APH2" that can modify gentamicin, kanamycin and related aminoglycosides. Plasmid pIP1 307 consists of pBR322 with a $2 \cdot 1-\mathrm{kb}$ HindIII insert carrying the aacA-aphD gene from a methicillin-resistant $S$. aureus strain isolated in France. This insert is derived, by deletion, from the $2 \cdot 5-\mathrm{kb}$ HindIII internal fragment of Tn400I, and contains, in addition to the aacA-aphD gene, a 297 -bp sequence from IS $256 .^{58}$

\section{Species identification of staphylococci}

Biochemical identification was as described previously, ${ }^{48}$ and included use of the ID 32 Staph gallery (API System, La Balme Les Grottes, France). ${ }^{62}$ Genomic identification involved hybridisation of $H$ HindII and EcoRI digests of bacterial DNA, separated by electrophoresis, with plasmid pBA2. Detection in the hybridisation patterns (HP) of the speciesspecific core of hybridising bands ${ }^{48}, 49$ allowed a precise species assignment.

\section{Susceptibility to antimicrobial agents}

Susceptibility to antimicrobial agents was determined with a disk diffusion assay ${ }^{63}$ and commercially available antibiotic disks (Diagnostics Pasteur, Marne La Coquette, France). Additional disks prepared in our laboratory contained streptogramin A $(20 \mu \mathrm{g})$, streptogramin B $(40 \mu \mathrm{g})$, cadmium acetate $(0.2 \mu \mathrm{mol})$, mercuric nitrate $(0 \cdot 2 \mu \mathrm{mol})$, sodium arsenate $(2 \mu \mathrm{mol})$, ethidium bromide $(200 \mu \mathrm{g})$, acriflavine $(200 \mu \mathrm{g})$, propamidine isethionate $(200 \mu \mathrm{g})$ or cetyltrimethylammonium bromide $(10 \mu \mathrm{g})$.

\section{Serotyping}

The isolates were typed by slide agglutination of formalin-killed strains as described previously. ${ }^{39}$ The following absorbed rabbit antisera, raised against the CNS strains in parentheses, were used: $52186(S$. epidermidis 52186); 52260 (S. epidermidis 52260); Epidermidis (ATCC 14990T); Hominis (ATCC 27844T); Warneri (ATCC 27836T); Haemolyticus (DSM 20263T); Simulans (ATCC 27848T); Capitis (ATCC 27840T); Saprophyticus (ATCC 15305T); Cohnii (DSM 20260); and Xylosus (DSM 20266T). Immunisation of rabbits and preparation of the absorbed hyperimmune antisera were as described previously. ${ }^{39}$

\section{Sodium dodecyl sulphate-polyacrylamide gel electrophoresis ( $S D S-P A G E$ ) and immunoblotting of bacterial proteins}

CNS isolates were grown overnight at $37^{\circ} \mathrm{C}$ in $10 \mathrm{ml}$ of medium containing $(\mathrm{g} / \mathrm{L})$ : synthetic broth AOAC (Difco) 17, casaminoacids (Difco) 17, yeast extract (Difco) 5, glucose 5. The resulting culture was centrifuged at $5000 \mathrm{~g}$ for $15 \mathrm{~min}$ at $4^{\circ} \mathrm{C}$. The cell pellet was suspended and washed three times in $5 \mathrm{ml}$ of $\mathrm{NaCl} 0.85 \% \mathrm{w} / \mathrm{v}$. The washed pellet was resuspended in $1 \mathrm{ml}$ of lysis solution $(\mathrm{NaCl} 0.85 \% \mathrm{w} / \mathrm{v}$; lysostaphin, Sigma $100 \mu \mathrm{g} / \mathrm{ml}$, and incubated at $37^{\circ} \mathrm{C}$ for $30 \mathrm{~min}$. Samples, containing an average of $500 \mu \mathrm{g}$ of protein, were solubilised by mixing in $4: 1$ proportions with $0.25 \mathrm{M}$ Tris $\mathrm{HCl}, \mathrm{pH} 6.8$, containing sodium dodecyl sulphate (SDS) $12.5 \% \mathrm{w} / \mathrm{v}$, glycerol $50 \% \mathrm{w} / \mathrm{v}$, dithiothreitol $7.7 \% \mathrm{w} / \mathrm{v}$, bromophenol blue sodium salt (Serva, Heidelberg, Germany) $0.005 \% \mathrm{w} / \mathrm{v}$, and boiled for $5 \mathrm{~min}$ before application to SDS-PAGE gels.

SDS-PAGE was performed as described by Laemmli, ${ }^{64}$ with an acrylamide $3.5 \% \mathrm{w} / \mathrm{v}$ stacking gel over an acrylamide $10 \% \mathrm{w} / \mathrm{v}$ separating gel. High and low molecular mass standards (BioRad Laboratories) were run as markers on each gel. The gels were stained with a solution containing Coomassie Brilliant Blue R250 (Sigma) 0.1\% w/v, ethanol $50 \% \mathrm{v} / \mathrm{v}$, acetic acid $10 \% \mathrm{v} / \mathrm{v}$, and destained with a solution containing ethanol $10 \% \mathrm{v} / \mathrm{v}$ and acetic acid $7 \% \mathrm{v} / \mathrm{v}$.

For immunoblotting, the separated proteins from unstained gels were transferred on to nitrocellulose membranes in $25 \mathrm{mM}$ Tris, $192 \mathrm{mM}$ glycine buffer, $\mathrm{pH} 8 \cdot 3$, containing methanol $20 \% \mathrm{v} / \mathrm{v}$, at $25^{\circ} \mathrm{C}$ with a current of $0.5 \mathrm{~A}$ applied for $45 \mathrm{~min}$ in a LKB Transblot cell. After transfer, the membranes were washed three times with $0.5 \mathrm{M}$ Tris, $0.1 \mathrm{M} \mathrm{NaCl}, \mathrm{pH} 8$. Free proteinbinding sites were then saturated by incubation at $37^{\circ} \mathrm{C}$ for $60 \mathrm{~min}$ in the same buffer supplemented with low-fat milk powder $1 \% \mathrm{w} / \mathrm{v}$ (Regilait écrémé, France Lait, France). The membranes were washed with the same buffer and then incubated at $37^{\circ} \mathrm{C}$ for $60 \mathrm{~min}$ with unabsorbed rabbit antiserum raised against $S$. epidermidis ATCC 14990T added to the blocking buffer to a final 100-fold dilution. The membranes were washed four times with blocking buffer and then incubated at $37^{\circ} \mathrm{C}$ for a further $75 \mathrm{~min}$ with horseradish peroxidase-linked goat anti-rabbit IgG (BioRad) diluted 1000-fold in blocking buffer. After 10 washes in blocking buffer, and a further five washes in the same buffer without milk, the membranes were stained with a solution containing diamino-benzidine tetrahydrochloride (Sigma) $0.05 \% \mathrm{w} / \mathrm{v}$ and $\mathrm{H}_{2} \mathrm{O}_{2} \quad 0.01 \%$ $\mathrm{v} / \mathrm{v}$ in $0 \cdot 1 \mathrm{M}$ Tris $\mathrm{HCl}, \mathrm{pH} 7 \cdot 6$.

\section{DNA isolation and analysis}

Total cellular DNA was isolated from CNS strains and purified as described previously. ${ }^{48}$ Plasmid DNA 
from $E$. coli strains was isolated and purified in a $\mathrm{CsCl}$-EtBr gradient. ${ }^{65} \mathrm{CNS}$ strains were screened for plasmid DNA with the rapid procedure described by Kado and Liu. ${ }^{66}$

Restriction endonucleases EcoRI and HindIII (Amersham International, Little Chalfont, Bucks) were used according to the manufacturer's instructions. Electrophoresis of digested DNA was carried out in agarose (Sigma) $0.8 \% \mathrm{w} / \mathrm{v}$ gels in Tris/borate buffer. ${ }^{65}$ Bacteriophage $\lambda$ DNA (Biolabs, New England, MA, USA) digested with $B g I I I$, a $1-\mathrm{kb}$ DNA ladder (Bethesda Research Laboratories, Inc., Cockeysville, MD, USA) and the Raoul I ladder (Appligene, Strasbourg, France) were used as molecular size markers.

DNA blotting and hybridisation. DNA was transferred from agarose gels to nitrocellulose filters with the bidirectional method described by Smith and Summers. ${ }^{67}$

Plasmids pBA2, pSF815A and pIP1307 were used as probes. Purified plasmid DNA was labelled with $\left[\alpha^{32} \mathrm{P}\right] \mathrm{dCTP}(3000 \mathrm{Ci} / \mathrm{mmol}$; Amersham International) with the Amersham Multiprime DNA labelling system as recommended by the manufacturer. The specific activity of the probes was $c .10^{9} \mathrm{cpm} / \mu \mathrm{g}$ of DNA. Hybridisation was performed under stringent conditions as described previously. ${ }^{48}$ The blots were exposed to Fuji RX film at $-70^{\circ} \mathrm{C}$, with intensifying screens, for between $24 \mathrm{~h}$ and several days.

Comparison of hybridisation patterns (HP). The average similarity between any two HP was assessed by the coefficient of Dice, ${ }^{68}$ calculated as follows:

Similarity $(\%)=\frac{\text { number of matching bands } \times 2}{\text { total number of bands }} \times 100$

\section{Results}

\section{Characteristics of the 17 CNS isolates from the same unit}

The isolates were speciated by determining their phenotypic characteristics and by analysis of the $H$ indIII and EcoRI cellular DNA fragments that hybridised with the pBA2 probe. The hybridisation patterns of the 17 isolates were compared with those known to be produced by different staphylococcal species. ${ }^{48,} 49$ Of the 17 isolates, 15 carried the $S$. epidermidis-specific core of common bands hybridising with pBA2; two isolates carried the $S$. haemolyticusspecific core of common bands. A good correlation was observed between the results obtained by phenotypic and genotypic speciation methods. Susceptibility to 27 antimicrobial agents was determined. All 17 isolates shared resistance to 10 antimicrobial agents (table I).

The isolates were typed with 11 different absorbed rabbit antisera raised against CNS. Three of the $15 S$. epidermidis isolates reacted with antisera 52186 and
Epidermidis; the other 12 strains were non-typable. The two $S$. haemolyticus isolates reacted with the absorbed sera prepared against the $S$. haemolyticus type strain, reinforcing the assignment to this species established on the basis of phenotypic and genotypic characteristics.

Whole cell polypeptide profiles were determined for the 17 isolates. The profiles of eight of these isolates are shown in fig. 1A. The comparative analysis of these profiles was difficult because of the large number of bands in each profile. Moreover, despite the use of standardised experimental conditions, the bands yielding distinguishable profiles within $S$. epidermidis were limited in number and not always reproducible. In contrast, the profiles of the $S$. haemolyticus isolates (e.g. fig. 1A, lane 9) were always distinguishable from those of the $S$. epidermidis isolates (fig. 1A, lanes 1-8).

Immunoblot patterns obtained with antisera raised against $S$. epidermidis strain ATCC 14990T revealed two clearly distinct patterns, I1 and I2, among the 15 $S$. epidermidis isolates. Although loaded with similar amounts of total cellular proteins, pattern I1 (fig. 1B, lanes 1-7) was characterised by a limited number of antigens reacting with the antiserum, whereas pattern I2 (fig. 1B, lane 8) consisted of a large number of bands. The patterns (pattern I3) of the two $S$. haemolyticus isolates (e.g., fig. 1B, lane 9) were identical, but were easily distinguished from patterns $\mathrm{Il}$ and I2 (fig. 1B, lanes 1-8).

The six distinct plasmid profiles detected among the 17 isolates are shown in fig. 2. The distribution of these profiles among the isolates is shown in table I. Profile P2 was predominant and was found in eight of the $S$. epidermidis isolates. Profile P1, with four bands in common with profile $\mathrm{P} 2$, was found in four $S$. epidermidis isolates. Three other profiles, P3, P4 and P5, occurred once only. The two $S$. haemolyticus isolates both had a profile, P6, which contained a single extrachromosomal DNA band that migrated in the same position as one of the bands of profiles P1, P2, P3 and P5 (fig. 2).

In addition to their use for speciation, the determination of HP between HindIII and EcoRI digests and pBA2 allowed four types to be distinguished among the $15 \mathrm{~S}$. epidermidis isolates: H20-E21 (10 isolates), H20-E46 (three isolates), H21-E21 (one isolate) and H21-E46 (one isolate). The two $S$. haemolyticus isolates both had the pattern H32-E30.

When the HindIII and EcoRI cellular DNA digests were hybridised with the pSF815A probe carrying the aacA-aphD gene, homology was detected with a $2 \cdot 5-$ $\mathrm{kb}$ HindIII fragment in all the isolates (fig. 3). In 14 of the $15 \mathrm{~S}$. epidermidis isolates, hybridisation was detected with an 18-kb EcoRI fragment (fig. 3), while in BM9877 (table I) hybridisation occurred with a 25$\mathrm{kb}$ EcoRI fragment (fig. 3). In the two S. haemolyticus isolates, hybridisation occurred with a $9 \cdot 2-\mathrm{kb}$ EcoRI fragment (fig. 3).

With pIP1307 as a probe, eight HindIII and five EcoRI HP were detected (fig. 3). With each isolate, 


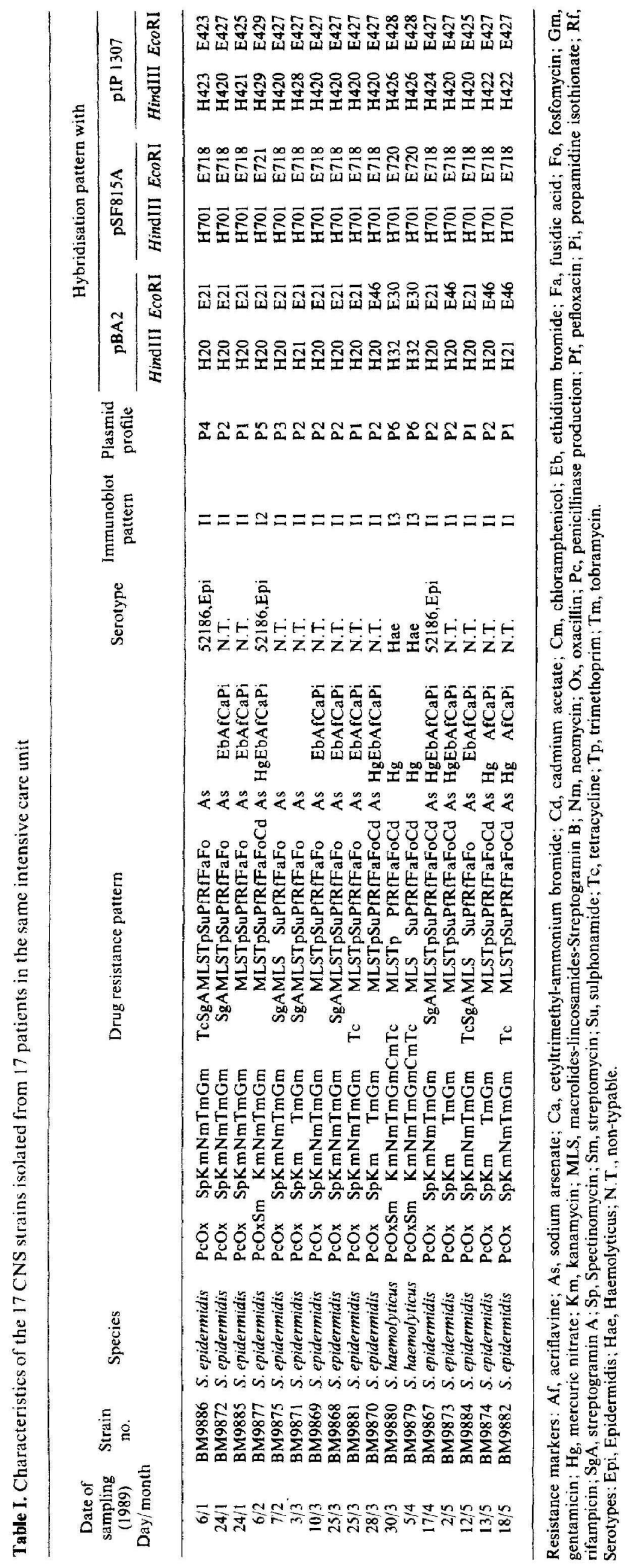



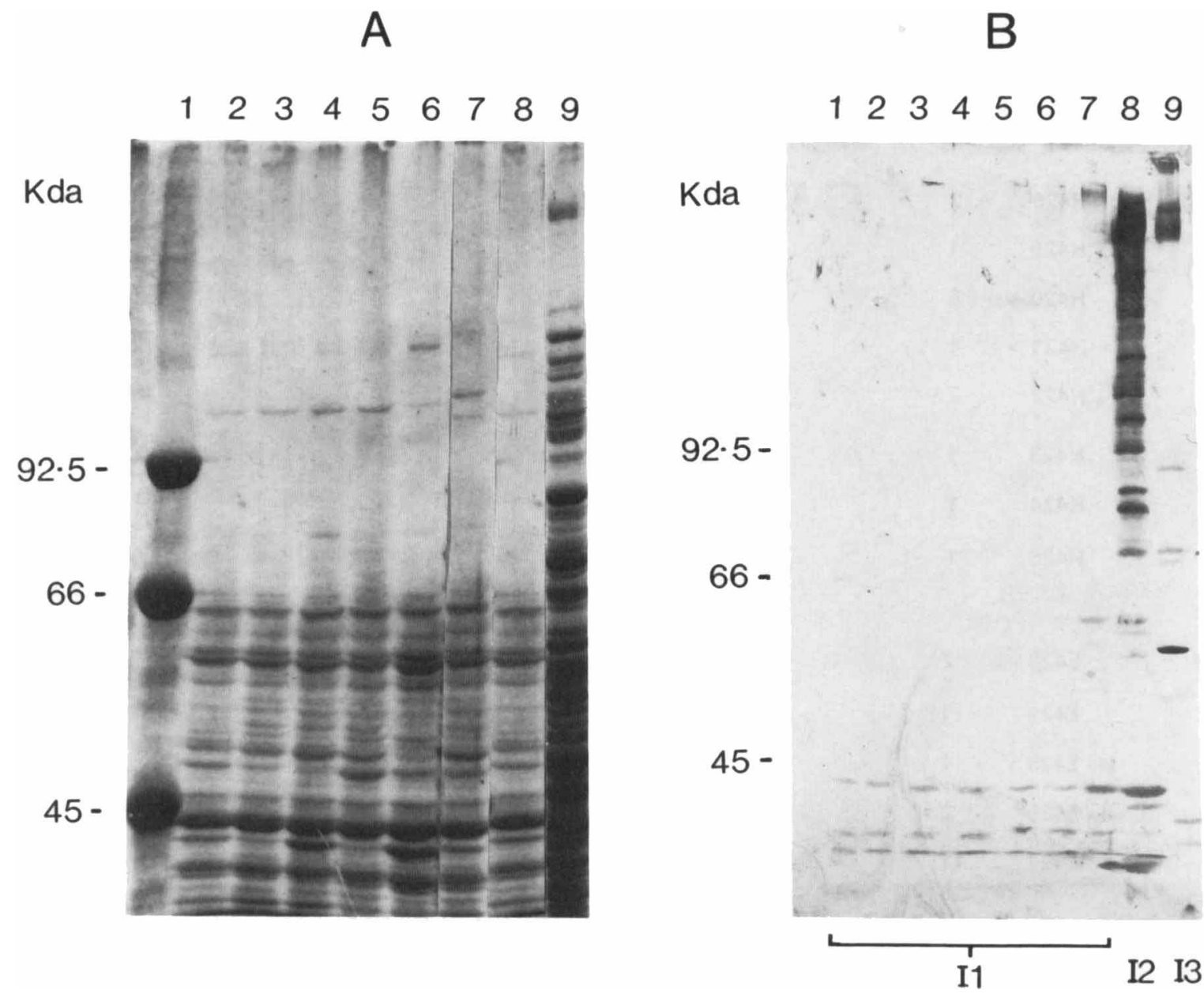

Fig. 1. Whole cell polypeptide profiles (A), and immunoblot patterns (B), obtained with a rabbit hyperimmune antiserum raised against $S$. epidermidis strain A TCC 14990T, for eight of the CNS isolates listed in table I. Lane 1, molecular size standards; 2, BM9871; 3, BM9885; 4, BM9886; 5, BM9867; 6, BM9882; 7, BM9873;8, BM9877; 9, BM9879.

hybridisation occurred with between four and nine $H$ HindII fragments and between three and six EcoRI fragments. At least two independent restriction enzyme digestions and hybridisation experiments were performed to ensure that the HP were reproducible.

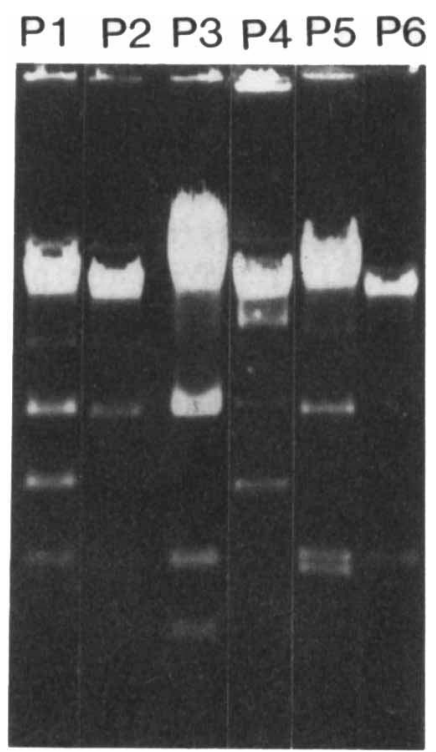

Fig. 2. Examples of the six plasmid profiles detected among the 17 CNS isolates included in the study.
The two $S$. haemolyticus isolates had the same HP, H426-E428 (fig. 3). These HP were compared with those of the $S$. epidermidis isolates by calculating the Dice coefficients. HP E428 showed no similarity with the four EcoRI HP detected among the $15 \mathrm{~S}$. epidermidis isolates, whereas HP H426 showed 18.1$36.3 \%$ similarity with the seven HindIII HP detected among these latter isolates. The H429-E429 HP of the S. epidermidis isolate BM9877 (table I) also showed low percentages of similarity with the HP of the other S. epidermidis isolates (15.3-25\% with the HindIII HP, but no similarity with the EcoRI HP). In contrast, higher percentages of similarity were observed among the HP of the 14 other $S$. epidermidis isolates $(66 \cdot 6-$ $88.8 \%$ for HindIII HP and $66.6-99 \%$ for the EcoRI HP).

Characteristics of the 38 S. epidermidis isolates originating from different geographical areas

These isolates were included in the study to evaluate the discriminatory power of the new typing methods used to compare the 17 isolates from the same unit.

Each of the 38 unrelated $S$. epidermidis isolates was characterised by its own drug resistance phenotype consisting of 2-19 resistance markers, but without any marker shared by all the isolates (results not shown). 


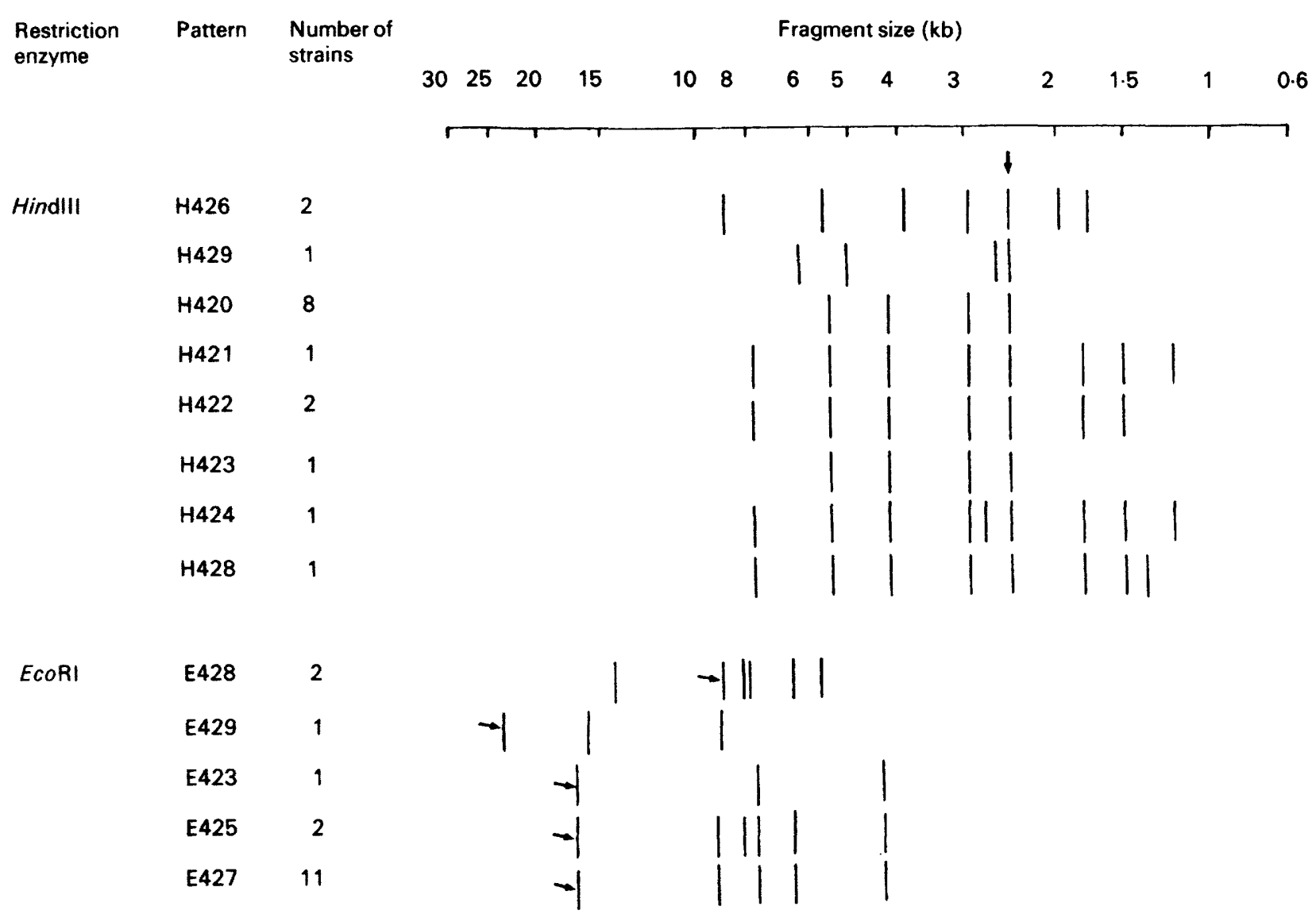

Fig. 3. Schematic representation of the hybridisation patterns obtained between HindIII and EcoRI digests of total cellular DNA and $\alpha-{ }^{32} \mathrm{P}$ labelled pIP1 307 . The bands marked with an arrow were those which hybridised also with the pSF815A probe.

Of the 38 unrelated $S$. epidermidis isolates, 27 reacted with either one or two of the three absorbed antisera raised against $S$. epidermidis strains. The typable isolates could be grouped into three serotypes: $52186-$ Epidermidis (22 isolates), 52186-52260 (three isolates) and 52186 (two isolates). None of the isolates reacted with the eight other absorbed antisera raised against strains belonging to other staphylococcal species.

Immunoblotting with the rabbit antiserum raised against $S$. epidermidis strain ATCC 14990T distinguished 30 immunoblot patterns among the 38 isolates analysed. The results obtained for eight of these isolates are shown in fig. $4 \mathrm{~B}$.

With the pBA2 probe, the 38 isolates were grouped into either nine or four types according to the HP obtained after cleavage of the cellular DNA with $H i n d I I I$ or EcoRI respectively. After cleavage with HindIII, two predominant HP were observed, H20 and $\mathrm{H} 51$, which accounted for 14 and 11 isolates respectively. The seven other $\mathrm{HP}$ observed were uncommon: $\mathrm{H} 21$ (one isolate), $\mathrm{H} 45$ (four isolates), $\mathrm{H} 47$ (one isolate), H50 (three isolates), H53 (one isolate), H55 (two isolates) and H56 (one isolate). After EcoRI cleavage, HP-E21 was predominant (34 isolates), whereas the other three HP observed-E45, E46 and E47-were rare (one, two and one isolates respectively). Combined use of HindIII and EcoRI allowed $11 \mathrm{HP}$ to be distinguished among the 38 isolates : H20-E21 (13 isolates), H51-E21 (11 isolates),
H45-E21 (four isolates), H50-E21 (three isolates), and a further seven combinations which accounted for one isolate each: H20-E45, H21-E46, H47-E21, H53E21, H55-E21, H55-E46 and H56-E47. All these HP, which have been described previously, ${ }^{48,49}$ contained the $S$. epidermidis-specific core of common bands. These results confirmed the assignment to $S$. epidermidis based on phenotypic characteristics.

None of the 19 isolates susceptible to gentamicin carried detectable nucleotide sequences that hybridised with pSF815A or pIP1307. In the 19 other isolates which were resistant to gentamicin, hybridisation was detected between the pSF815A probe and a $2 \cdot 5-\mathrm{kb}$ HindIII fragment (fig. 5A), and EcoRI fragments of various sizes (fig. 5C) which identified 15 distinct EcoRI HP. With the pIP1307 probe, hybridisation was detected with between one and 11 HindIII fragments (fig. 5A) and between one and seven EcoRI fragments (fig. 5B). Twelve distinct HindIII HP (fig. 5A) and 19 distinct EcoRI HP (fig. 5B) were detected among the 19 gentamicinresistant isolates. The eight isolates with the same HindIII HP had a single HindIII fragment of $2.5 \mathrm{~kb}$ that hybridised with pIP1307 (fig. 5A). Each of the isolates with more than one HindIII fragment that hybridised with pIP1307 was characterised by its own HindIII HP. The HP were compared by calculating the Dice coefficient. ${ }^{68}$ The extreme values observed were $0-40 \%$ for the $19 E c o$ RI HP and $12 \cdot 5-60 \%$ for 


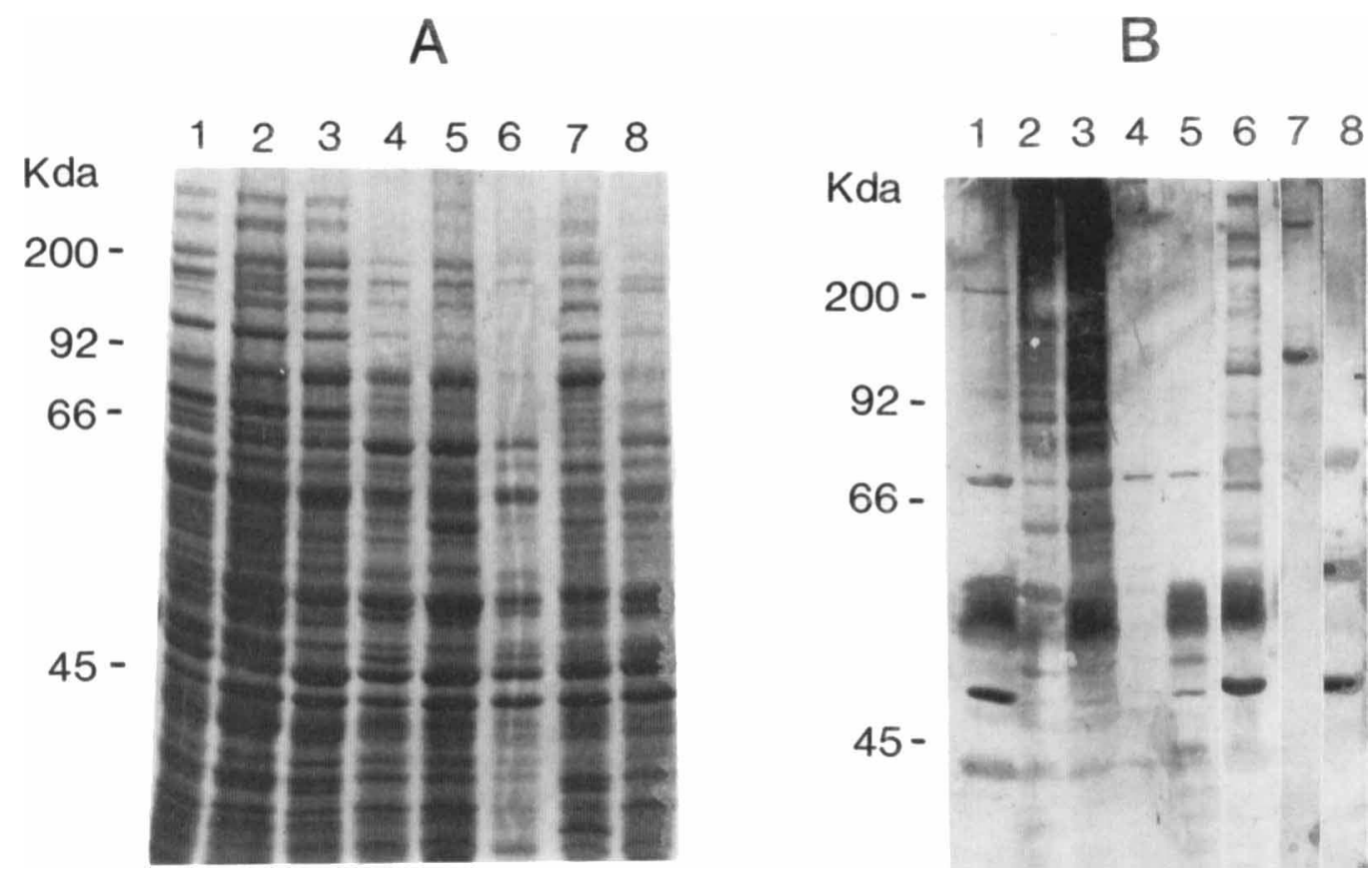

Fig. 4. Whole cell polypeptide profiles (A) of eight epidemiologically unrelated isolates of $S$. epidermidis, and the immunoblot patterns (B) obtained with rabbit hyperimmune antisera raised against $S$. epidermidis ATCC 14990T.

the 12 HindIII HP. When recalculated after eliminating the HindIII HP consisting of a single $2 \cdot 5-\mathrm{kb}$ HindIII band, the extreme values were $12.5-50 \%$.

Table II summarises the characteristics of all $53 \mathrm{~S}$. epidermidis isolates included in this study.

\section{Discussion}

In addition to a precise speciation, eight typing methods have been used to type CNS isolates, including analysis of immunoblot patterns and determination of HP obtained with three probes used previously to type $S$. aureus isolates. ${ }^{58}$ The ability to discriminate between CNS strains by these latter methods was evaluated by examining 38 unrelated $S$. epidermidis isolates originating from different geographical areas. Analysis of immunoblot patterns showed that the use of unabsorbed antiserum raised against strain ATCC 14990T yielded the largest number of distinct types among the 38 unrelated $S$. epidermidis isolates (results not shown). The pBA2 probe allowed detection of re-arrangements occurring in the rRNA gene clusters or in the adjacent chromosomal sequences. In contrast with the results observed among $S$. aureus isolates, ${ }^{58}$ within $S$. epider-

Table II. Summary of the characteristics of the 53 S. epidermidis isolates studied

\begin{tabular}{|c|c|c|c|c|}
\hline \multirow{3}{*}{ Typing method } & \multicolumn{4}{|c|}{ Characteristics of } \\
\hline & \multicolumn{2}{|c|}{38 unrelated isolates } & \multicolumn{2}{|c|}{15 isolates from the same unit } \\
\hline & $\begin{array}{l}\text { Number of } \\
\text { typable } \\
\text { isolates }\end{array}$ & $\begin{array}{l}\text { Number of } \\
\text { distinct } \\
\text { types }\end{array}$ & $\begin{array}{l}\text { Number of } \\
\text { typable } \\
\text { isolates }\end{array}$ & $\begin{array}{l}\text { Number of } \\
\text { distinct } \\
\text { types }\end{array}$ \\
\hline Drug resistance pattern & 38 & 38 & 15 & 12 \\
\hline Serotype & 27 & 3 & 3 & 1 \\
\hline $\begin{array}{l}\text { Immunoblot with antiserum } \\
\text { against ATCC 14990T }\end{array}$ & 38 & 30 & 15 & 2 \\
\hline $\begin{array}{l}\text { HP between pBA2 and } \\
- \text { HindIII digests } \\
-E c o \mathrm{RI} \text { digests } \\
-E c o \mathrm{RI}+\text { HindIII digests }\end{array}$ & $\begin{array}{l}38 \\
38 \\
38\end{array}$ & $\begin{array}{r}9 \\
4 \\
11\end{array}$ & $\begin{array}{l}15 \\
15 \\
15\end{array}$ & $\begin{array}{l}2 \\
2 \\
4\end{array}$ \\
\hline $\begin{array}{l}\text { HP between pSF815A and } \\
\text {-HindIII digests } \\
\text {-EcoRI digests }\end{array}$ & $\begin{array}{l}19 \\
19\end{array}$ & $\begin{array}{r}1 \\
15\end{array}$ & $\begin{array}{l}15 \\
15\end{array}$ & $\begin{array}{l}1 \\
2\end{array}$ \\
\hline $\begin{array}{l}\text { HP between pIP1307 and } \\
\text {-HindIII digests } \\
\text {-EcoRI digests }\end{array}$ & $\begin{array}{l}19 \\
19\end{array}$ & $\begin{array}{l}12 \\
19\end{array}$ & $\begin{array}{l}15 \\
15\end{array}$ & $\begin{array}{l}7 \\
4\end{array}$ \\
\hline
\end{tabular}



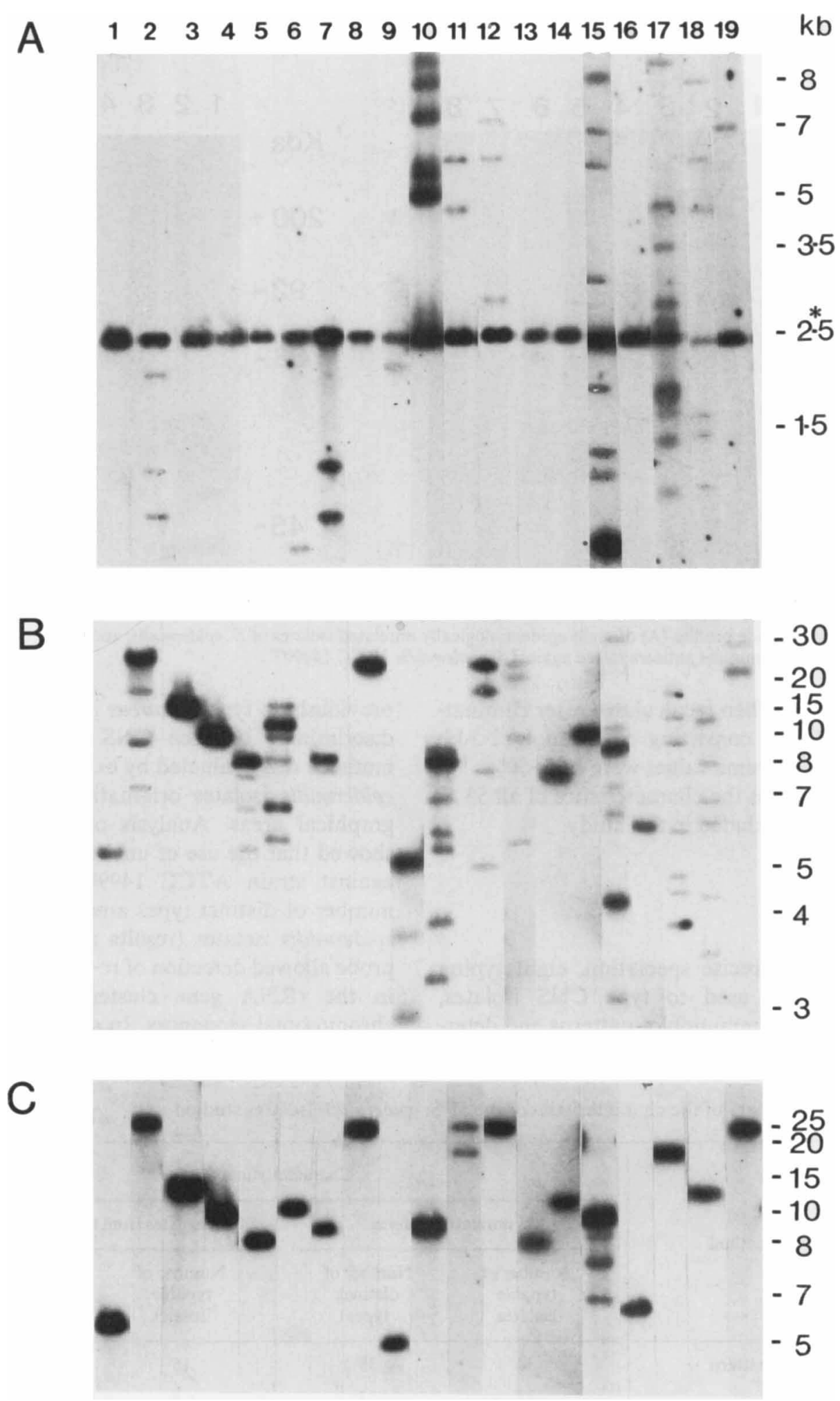

Fig. 5. Autoradiographs of cellular DNA from 19 epidemiologically unrelated S. epidermidis isolates, digested with HindIII (A) or EcoRI (B), and probed with labelled pIP1307 (A and B) or pSF815A (C). The 2.5-kb HindIII band marked with an asterisk in (A) hybridised also with pSF815A.

midis isolates the use of HindIII allowed detection of a greater heterogeneity in HP than that detected following use of EcoRI. The patterns H20, H51 and E21 were predominant among the unrelated CNS isolates; therefore, only isolates having other patterns can be differentiated accurately with the pBA2 probe. Despite the low discriminatory power of this method, its use is recommended since it enables a precise speciation of $\mathrm{CNS}^{48,49}$ as a first step in typing.

With the two other probes, pSF815A and pIP1307, a greater diversity in patterns was observed among the unrelated $S$. epidermidis isolates. These two probes, which carry the gene $a a c A-a p h D$, appeared to be useful only for typing gentamicin-resistant isolates. In 
each isolate, the gene $a a c A-a p h D$ was located on a $2 \cdot 5$ $\mathrm{kb}$ HindIII fragment, suggesting that the isolates carry genetic elements identical or similar to $\operatorname{Tn} 4001^{69,70}$ or $\mathrm{Tn} 4031^{71}$ since the aacA-aphD gene of these transposons is also situated within a $2 \cdot 5-\mathrm{kb}$ HindIII internal fragment. In 13 of the unrelated isolates, several EcoRI and HindIII fragments were detected that hybridised with the pIP1307 probe. This probe contains, in addition to the $a a c A-a p h D$ gene, part of IS256. Fragments hybridising with pIP1307, but not with the $a a c A-a p h D$ gene, carry sequences homologous to IS256, but such sequences were not detected in any of the gentamicin-susceptible unrelated $S$. epidermidis isolates that were tested. Recent studies have shown that the EcoRI and HindIII fragments carrying these sequences also hybridised with a probe consisting of an amplified DNA sequence corresponding to the ORF390 of IS256 (K. Dyke and N. El Solh, unpublished observations). These results may reflect the presence of multiple copies of IS256 in the isolates carrying such sequences. Further studies are needed to verify this hypothesis. The preferential use of pIP1307 as a probe is recommended because of the generation of complex HP, thereby allowing easy fingerprinting, and because of the greater diversity obtained when compared with pSF815A (19 compared with $15 E c o$ RI HP, and 12 compared with one HindIII HP among the 19 unrelated $S$. epidermidis isolates). Thus the detection of identical HP with pIP1307 as a probe would be good evidence that two strains are closely related.

Among the 17 CNS strains that were isolated in the same unit and shared 11 drug resistance markers, phenotypic as well as genotypic speciation methods separated two $S$. haemolyticus isolates from $15 S$. epidermidis isolates. The two $S$. haemolyticus isolates were closely related by all typing methods tested.

\section{References}

1. Kloos WE, Schleifer KH. Genus IV. Staphylococcus Rosenbach $188418^{\mathrm{AL}}$, (Nom. Cons. Opin. 17 Jud. Comm. 1958. 153). In: Sneath PHA (ed) Bergey's Manual of systematic bacteriology, vol 2, Baltimore, Williams and Wilkins. 1986: 1013-1035

2. Archer GL, Armstrong BC. Alteration of staphylococcal flora in cardiac surgery patients receiving antibiotic prophylaxis. $J$ Infect Dis 1983; 147: 642-649.

3. Bint AJ, Finch RG, Gokal R, Goldsmith HJ, Junor B, Oliver D. Diagnosis and management of peritonitis in continuous ambulatory peritoneal dialysis. (Report of a working party of the British Society for Antimicrobial Chemotherapy) Lancet 1987; 1: 845-849.

4. Bor DH, Rose RM, Modlin JF, Weintraub R, Friedland GH. Mediastinitis after cardiovascular surgery. Rev Infect Dis 1983; 5: 885-897.

5. Dismukes WE. Prosthetic valve endocarditis: factors influencing outcome and recommendations for therapy. In: Bisno AL (ed) Treatment of infective endocarditis. New York, Grune and Stratton. 1981: 167-191.

6. Eisenberg ES, Ambalu M, Szylagi G, Aning V, Soeiro R Colonization of skin and development of peritonitis due to coagulase-negative staphylococci in patients undergoing peritoneal dialysis. $J$ Infect $D$ is $1987 ; 156$ : 478-482.

7. Gemmell CG. Pathogenicity of coagulase-negative staphylo-
Analysis of immunoblot patterns and percentages of similarity between the HP obtained with pIP1307 enabled a clear-cut distinction between BM9877 (table I) and the 14 other $S$. epidermidis isolates. The immunoblot patterns of these latter isolates were characterised by a limited number of bands and were not distinguishable reproducibly. In addition, the $a a c A-a p h D$ gene carried by these 14 isolates was located on an $E c o$ RI fragment of the same size, while the HP obtained with pIP1307 had greater similarity $(66.6-99 \%)$ than any value detected between the HP of the unrelated $S$. epidermidis isolates. Within this group of 14 S. epidermidis isolates, strains BM9872 and BM9868 (table I) were indistinguishable from each other. Similarly, strains BM9870 and BM9873 were indistinguishable and, since they shared the same uncommon pBA2 HP (H20-E46) and the same plasmid profile (P2), these strains were also related closely to strain BM9874.

In conclusion, the CNS strains isolated from the same unit that carried an unusual combination of four drug resistance markers resulted mostly from the spread of an epidemic strain, but also from the occasional independent selection of unrelated isolates by the four drugs commonly used in the unit. Determination of drug resistance phenotypes was useful in indicating the possibility of epidemic spread of closely related isolates in the unit, but was not sufficient by itself to confirm this hypothesis. The use of several different typing methods was necessary for a proper epidemiological assessment. Speciation, analysis of immunoblot patterns, and determination of HP with pIP1307 as a probe were the methods that yielded the most conclusive results.

We thank K. Dyke for criticism of the manuscript, Anne Buree, Annie Buu-Hoï and G. Ann Hébert for providing strains, and Odette Rouelland for secretarial assistance. cocci with respect to the nature of the host response Zentralbl Bakteriol Hyg A 1987; 266: 52-59.

8. Karchmer AW, Archer GL, Dismukes WE. Staphylococcus epidermidis causing prosthetic valve endocarditis: microbiologic and clinical observations as guides to therapy. Ann Intern Med 1983; 98: 447-455.

9. Phillips I (ed). Focus on coagulase negative staphylococci. London, Royal Society of Medicine Services, International Congress and Symposium Series No. 151. 1989.

10. Sidebottom DG, Freeman J, Platt R, Epstein MF, Goldmann DA. Fifteen-year experience with bloodstream isolates of coagulase-negative staphylococci in neonatal intensive care. J Clin Microbiol 1988; 26: 713-718.

11. Winston DJ, Dudnick DV, Chapin M, Ho WG, Gale RP, Martin WJ. Coagulase-negative staphylococcal bacteremia in patients receiving immunosuppressive therapy. Arch Intern Med 1983; 143: 32-36.

12. Archer GL, Vishniavsky N, Stiver HG. Plasmid pattern analysis of Staphylococcus epidermidis isolates from patients with prosthetic valve endocarditis. Infect Immun 1982; 35: 627-632.

13. Boyce JM, Potter-Bynoe G, Opal SM, Dziobek L, Medeiros AA. A common-source outbreak of Staphylococcus epidermidis infections among patients undergoing cardiac surgery. J Infect Dis 1990; 161 : 493-499.

14. Christensen GD, Bisno AL, Parisi JT, McLaughlin B, Hester MG, Luther RW. Nosocomial septicaemia due to multiply 
antibiotic-resistant Staphylococcus epidermidis. Ann Intern Med 1982; 96: 1-10

15. Ludlam HA, Noble WC, Marples RR, Bayston R, Phillips I. The epidemiology of peritonitis caused by coagulasenegative staphylococci in continuous ambulatory peritoneal dialysis. J Med Microbiol $1989 ; 30: 167-174$.

16. Mickelsen PA, Plorde JJ, Gordon KP et al. Instability of antibiotic resistance in a strain of Staphylococcus epidermidis isolated from an outbreak of prosthetic valve endocarditis. J Infect Dis 1985; 152: 50-58.

17. Van Den Broek PJ, Lampe AS, Berbée GAM, Thompson I, Mouton RP. Epidemic of prosthetic valve endocarditis caused by Staphylococcus epidermidis. Br Med J 1985; 291 : $949-950$

18. Christensen GD. Baddour LM, Madison BM et al. Colonial morphology of staphylococci on Memphis agar: phase variation of slime production, resistance to $\beta$-lactam antibiotics, and virulence. $J$ Infect Dis 1990; 161: 11531169

19. Etienne J, Renaud F, Bes $M$ et al. Instability of characteristics amongst coagulase-negative staphylococci causing endocarditis. J Med Microbiol 1990; 32: 115-122.

20. Richardson JF, Marples RR. Changing resistance to antimicrobial drugs, and resistance typing in clinically significant strains of Staphylococcus epidermidis. J Med Microbiol $1982 ; 15: 475-484$

21. Marples RR. Laboratory assessment in the epidemiology of infections caused by coagulase-negative staphylococci. $J$ Med Microbiol 1986; $22: 285-286$

22. Parisi JT, Lampson BC, Hoover DL, Khan JA. Comparison of epidemiologic markers for Staphylococcus epidermidis. I Clin Microbiol 1986; $24: 56-60$.

23. Pfaller MA, Herwladt LA. Laboratory, clinical, and epidemiological aspects of coagulase-negative staphylococci. Clin Microbiol Rev 1988; 1: 281-299.

24. Thore M, Kühn I, Löfdahl S, Burman LG. Drug-resistant coagulase-negative skin staphylococci. Epidemiol Infect 1990: 105: 95-105.

25. Hartstein Al, Valvano MA, Morthland VH, Fuchs PC, Potter SA, Crosa JH. Antimicrobic susceptibility and plasmid profile analysis as identity tests for multiple blood isolates for coagulase-negative staphylococci. J Clin Microbiol 1987; $25: 589-593$.

26. Hébert GA, Cooksey RC, Clark NC, Hill BC, Jarvis WR, Thornsberry C. Biotyping coagulase-negative staphylococci. J Clin Microbiol 1988; $26: 1950-1956$.

27. Ludlam HA, Noble WC, Marples RR, Phillips I. The evaluation of a typing scheme for coagulase-negative staphylococci suitable for epidemiological studies. $J$ Med Microbiol 1989 ; 30: $161-165$

28. Parisi JT, Hamory BH. Simplified method for the isolation, identification, and characterisation of Staphylococcus epidermidis in epidemiologic studies. Diagn Microbiol Infect Dis 1986; $4: 29-35$.

29. Schumacher-Perdreau F, Jansen B, Peters G, Pulverer G Typing of coagulase-negative staphylococci isolated from foreign body infections. Eur $J$ Clin Microbiol Infect Dis $1988 ; 7: 270-273$.

30. Froggatt JW, Johnston JL, Galetto DW, Archer GL. Antimicrobial resistance in nosocomial isolates of Staphylococcus haemolyticus. Antimicrob Agents Chemother 1989; 33: 460 466.

31. Witte W, Braulke C, Halle E, Spencker FB, Handrick W Typing of multiple isolates of coagulase-negative staphylococci from blood cultures and cerebrospinal fluid in neonates and children: an approach to discriminate contaminants. Zentralbl Bakteriol 1990; 274: 382-389.

32. Bes $M$, Brun $Y$, Fleurette J. Nouveaux bactériophages de Staphylococcus epidermidis: évaluation de leur intérêt épidémiologique. Ann Microbiol (Inst Pasteur) 1984; 135B $165-176$.

33. de Saxe MJ, Crees-Morris JA, Marples RR, Richardson JF Evaluation of current phage-typing systems for coagulasenegative staphylococci. Zentralbl Bakteriol 1981; Suppl 10: 197-204.

34. Marples RR, Richardson JF. Characters of coagulase-negative staphylococci collected for a collaborative phage-typing study. Zentralbl Bakteriol 1981 ; Suppl 10: 175-180.

35. Martín-de-Nicolas MM, Vindel A, Sáez-Nieto JA. Development of a new set of phages as an epidemiological marker in Staphylococcus epidermidis causing nosocomial infections. Epidemiol Infect 1990; 104: 111-118.

36. Richardson JF, Marples RR. Phage typability of coagulasenegative staphylococci in relation to antibiotic resistance. Zentralbl Bakteriol 1987; Suppl 16: 235-246.

37. Rosdahl VT, Gahrn-Hansen B, Møller JK, Kjaeldgaard P. Phage-typing of coagulase-negative staphylococci. APMIS 1990; 98: 299-304

38. Verhoef J, Van Boven CPA, Winkler KC. Phage-typing of coagulase-negative staphylococci. J Med Microbiol 1972; 5: $9-19$

39. Pillet J, Orta B. Analyse sérologique des staphylocoques coagulase négatifs: étude des agglutinogènes caractéristiques des souches types des neuf espèces individualisées par Schleifer et Kloos. Ann Microbiol (Inst Pasteur) 1977; I28B : $475-486$

40. Archer GL. Molecular epidemiology of multiresistant Staphylococcus epidermidis. J Antimicrob Chemother 1988;21 Suppl C: $133-138$

41. Archer GL, Karchmer AW, Vishniavsky N, Johnston JL Plasmid-pattern analysis for the differentiation of infecting from noninfecting Staphylococcus epidermidis. I Infect Dis $1984 ; 149: 913-920$.

42. Brown E, Wenzel RP, Hendley JO. Exploration of the microbial anatomy of normal human skin by using plasmid profiles of coagulase-negative staphylococci: search for the reservoir of resident skin flora. $J$ Infect Dis $1989 ; 160$ : 644-650.

43. Etienne J, Poitevin-Later F, Renaud F, Fleurette J. Plasmid profiles and genomic DNA restriction endonuclease patterns of 30 independent Staphylococcus lugdunensis strains. FEMS Microbiol Lett 1990; 67: 93-98.

44. Parisi JT, Hecht DW. Plasmid profiles in epidemiologic studies of infections by Staphylococcus epidermidis. $J$ Infect Dis $1980 ; 141$ : $637-643$.

45. Bialkowska-Hobrzanska $H$, Jaskot D, Hammerberg O. A method for DNA restriction endonuclease fingerprinting of coagulase-negative staphylococci. J Microbiol Meth $1990 ; 12: 41-49$

46. Burnie JP, Lee W. A comparison of DNA and immunoblot fingerprinting of the SII biotype of coagulase negative staphylococci. Epidemiol Infect 1989; 101 : 203-212.

47. Bialkowska-Hobrzanska H, Harry V, Jaskot D, Hammerberg $O$. Typing of coagulase-negative staphylococci by Southern hybridization of chromosomal DNA fingerprints using a ribosomal RNA probe. Eur J Clin Microbiol Infect Dis $1990 ; 9: 588-594$.

48. De Buyser M-L, Morvan A, Grimont F, El Solh N. Characterization of Staphylococcus species by ribosomal RNA gene restriction patterns. J Gen Microbiol 1989; 135 : 989-999.

49. El Solh N, De Buyser ML, Morvan A et al. Use of Bacillus subtilis $16 \mathrm{~S}$ rRNA as a probe to identify species, subspecies, and types in the genus staphylococcus. In: Novick RP, Skurray RA (eds) Molecular biology of staphylococci. 1990: 585-593.

50. Pennington TH, Harker C, Thompson-Carter F. Identification of coagulase-negative staphylococci by using sodium dodecyl sulfate-polyacrylamide gel electrophoresis and rRNA restriction patterns. J Clin Microbiol 1991; $29: 390$ 392.

51. Thompson-Carter FM, Carter PE, Pennington TH. Differentiation of staphylococcal species and strains by ribosomal RNA gene restriction patterns. J Gen Microbiol 1989; 135 : 2093-2097.

52. Burnie JP, Lee W, Matthews RC, Bayston R. Immunoblot fingerprinting of coagulase-negative staphylococci. $J$ Clin Pathol 1988; 41 : 103-110.

53. Clink J, Pennington TH. Staphylococcal whole-cell polypeptide analysis: evaluation as a taxonomic and typing tool. $J \mathrm{Med}$ Microbiol 1986; $22: 41-44$

54. Maggs AF, Pennington TH. Temporal study of staphylococcal species on the skin of human subjects in isolation and clonal analysis of Staphylococcus capitis by sodium dodecyl sulfate-polyacrylamide gel electrophoresis. J Clin Microbiol $1989 ; 27: 2627-2632$.

55. Stephenson JR, Tabaqchali S. New method for typing coagulase-negative staphylococci. J Clin Pathol 1986; 39: 12711275

56. Thompson-Carter FM, Pennington TH. Characterization of coagulase-negative staphylococci by sodium dodecyl sul- 
fate-polyacrylamide gel electrophoresis and immunoblot analyses. J Clin Microbiol 1989; 27 : 2199-2203.

57. Kotilainen P, Huovinen P, Eerola E. Application of gas-liquid chromatographic analysis of cellular fatty acids for species identification and typing of coagulase-negative staphylococci. J Clin Microbiol 1991; 29 : 315-322.

58. Monzon-Moreno C, Aubert S, Morvan A, El Solh N. Usefulness of three probes in typing methicillin resistant Staphylococcus aureus (MRSA) strains. J Med Microbiol 1991 ; 34: 8088.

59. Iglesias A, Ceglowski P, Trautner TA. Plasmid transformation in Bacillus subtilis. Effects of the insertion of Bacillus subtilis rRNA genes into plasmids. Mol Gen Genet 1983; 192: 149155.

60. Ferretti JJ, Gilmore KS, Courvalin P. Nucleotide sequence analysis of the gene specifying the bifunctional 6'-aminoglycoside acetyltransferase $2^{\prime \prime}$-aminoglycoside phosphotransferase enzyme in Streptococcus faecalis and identification and cloning of gene regions specifying the two activities. J Bacteriol 1986; 167: 631-638.

61. El Solh N, Moreau N, Ehrlich SD. Molecular cloning and analysis of Staphylococcus aureus chromosomal aminoglycoside resistance genes. Plasmid 1986; 15: 104-118.

62. Brun Y, Bes M, Boeufgras JM et al. International collaborative evaluation of the ATB 32 Staph gallery for identification of the Staphylococcus species. Zentralbl Bakteriol 1990; 273: $319-326$.

63. El Solh N, Allignet J, Bismuth R, Buret B, Fouace J-M. Conjugative transfer of staphylococcal antibiotic resistance markers in the absence of detectable plasmid DNA. Antimicrob Agents Chemother 1986; 30: 161-169.

64. Laemmli UK. Cleavage of structural proteins during the assembly of the head of bacteriophage T4. Nature 1970; 227: 680-685.

65. Sambrook J, Fritsch EF, Maniatis T. Molecular cloning: a laboratory manual, 2nd edn. Cold Spring Harbor, NY, Cold Spring Harbor Laboratory Press. 1989.

66. Kado CI, Liu S-T. Rapid procedure for detection and isolation of large and small plasmids. J Bacteriol 1981 ; 145: 13651373 .

67. Smith GE, Summers MD. The bidirectional transfer of DNA and RNA to nitrocellulose or diazobenzyloxymethyl-paper. Anal Biochem 1980; 109: 123-129.

68. Dice LR. Measures of the amount of ecologic association between species. Ecology 1945; 26: 297-302.

69. Byrne ME, Rouch DA, Skurray RA. Nucleotide sequence analysis of IS256 from the Staphylococcus aureus gentamicin-tobramycin-kanamycin-resistance transposon Tn4001. Gene 1989; 81 : 361-367.

70. Rouch DA, Byrne ME, Kong YC, Skurray RA. The aacA-aphD gentamicin and kanamycin resistance determinant of Tn400I from Staphylococcus aureus; expression and nucleotide sequence analysis. J Gen Microbiol 1987; 133: 30393052.

71. Thomas WD, Archer GL. Mobility of gentamicin resistance genes from staphylococci isolated in the United States: identification of Tn4031, a gentamicin resistance transposon from Staphylococcus epidermidis. Antimicrob Agents Chemother 1989; 33: 1335-1341. 